\title{
TEORETYCZNE I PRAWNE ASPEKTY KORUPCJI W SEKTORZE PRYWATNYM
}

\section{WSTĘP}

Korupcja zmienia swe oblicze w zależności od rozwoju gospodarki rynkowej, sektora prywatnego, konkurencyjności, wzajemnego oddziaływania instytucji formalnych i nieformalnych, których jest elementem określającym koszty transakcji. Źródła korupcji mają charakter uniwersalny i specyficzny, strukturalny (ekonomiczny, społeczny, polityczny) oraz psychologiczny, wynikający z tej części natury ludzkiej, która odpowiada za biologiczną potrzebę przeżycia, stabilizacji, kontroli rzeczywistości, gromadzenia czy chciwości. Ogólne warunki, w jakich dochodzi do korupcji, to: istnienie dóbr dzielonych (rzadkich), osoba odpowiedzialna za ten podział, zasady dystrybucji formalnie i społecznie uznane za obowiązujące, naruszanie zasad i intencji uważanych za obowiązujące w tych zasadach dystrybucji przez osobę za ich przestrzeganie odpowiedzialną, osiąganie przez tę osobę korzyści głównie materialnych lub obietnicy tych korzyści.

W powszechnym rozumieniu korupcja dotyczy sektora publicznego, głównie $\mathrm{w}$ relacjach ze sferą prywatną. Tymczasem uniwersalne atrybuty korupcji obowiązują także w procesie gospodarowania dobrami prywatnymi, czyli w sektorze prywatnym, w obrębie podmiotów prywatnych oraz w relacjach między nimi. Korupcja należy do nadużyć naruszających interes organizacji oraz funkcjonujące prawo. Przestępstwo gospodarcze, a do takich należy również korupcja w sektorze prywatnym, jest zamachem na podstawy społeczne i gospodarcze obrotu handlowego, tj. rzetelność, uczciwość i równość szans podmiotów działających w ramach gospodarki rynkowej. Dla gospodarki narodowej równie szkodliwe, a może i bardziej niż korupcja funkcjonariuszy publicznych, jest przekupstwo w sektorze prywatnym. Wynika nie tylko z przyczyn o charakterze uniwersalnym, ale też ze specyficznych warunków gospodarek, branż i firm. Jest nie tylko przeżytkiem i swoistym archetypem, ale wynika $z$ rozwoju stosunków własności i systemu kre- 
dytowego, który usankcjonował zasadę ograniczonej odpowiedzialności, zmniejszył twarde ograniczenia budżetowe. Obecnie uległ rozluźnieniu ścisły związek między materialną i społeczną pozycją osób odpowiedzialnych za podejmowane decyzje a finansowym statusem kierowanych przez nich przedsiębiorstw, co zachęcało do podejmowania nieodpowiedzialnych decyzji w kwestii pożyczek, inwestowania i rozbudowy firm oraz stwarzało pokusy korupcyjne.

Korupcja komercyjna jest zagadnieniem stosunkowo nowym, którym odpowiednie instytucje zajęły się dopiero pod koniec lat 90 . Schyłek XX wieku był faktycznym początkiem walki z tym obszarem nieprawidłowości w skali międzynarodowej, co oznacza, że stał się on problemem ekonomicznym, prawnym i społecznym. W artykule podejmiemy problem z perspektywy mikroekonomicznej, mając świadomość, że korupcja wynika w istotny sposób z uwarunkowań makropolitycznych i ekonomicznych. Zagadnienie to jeszcze nie doczekało się uznania swojej wagi w naukach ekonomicznych. Jednak teoria ekonomii umożliwia ujęcie korupcji w sektorze prywatnym. Od wielu lat funkcjonuje ono w ustawodawstwie. Artykuł ten jest próbą prezentacji teoretycznych możliwości oraz uporządkowania rozwiązań ustawodawczych.

\section{TEORIE EKONOMICZNE A PROBLEM KORUPCJ}

Defraudacje i korupcja to przypuszczalnie jeden z najistotniejszych czynników ryzyka we współczesnej gospodarce, i to pomimo regularnych kontroli wewnętrznych i zewnętrznych. Straty z tytułu nadużyć to około $5 \%$ rocznych przychodów firm, co w skali globalnej daje 1,5 bln USD rocznie (w 2006 r. w USA było to 652 mld USD $)^{1}$. Badanie przeprowadzone na zlecenie Transparency International - Global Corruption Barometer 2009 - w 69 krajach wskazuje na narastający problem korupcji sektora prywatnego, który za skorumpowany uznała połowa badanych, czyli o 8\% więcej niż w czasie sondażu sprzed 5 lat² ${ }^{2}$. Wśród 16 krajów UE oraz w Islandii, Norwegii, Szwajcarii i Izraelu za najbardziej skorumpowany uznały sektor prywatny osoby z Danii (53\% badanych), Islandii (55\%), Luksemburga (43\%), Holandii (58\%), Norwegii (62\%), Portugalii (33\%), Hiszpanii (29\%) i Szwajcarii (29\%). W Polsce było to 21\%. W Hongkongu, gdzie skuteczna walka z korupcją, głównie w sektorze publicznym, trwa już od ponad 20 lat, właśnie

${ }^{1}$ N. Iyer, M. Samociuk, Defraudacja i korupcja. Zapobieganie i wykrywanie, Wydawnictwo Naukowe PWN, Warszawa 2007, s. 6; Zarządzanie ryzykiem nadużý, Ernst \& Young 2007, http://weba01.com.pl/EYP/WEB/eycom_download.nsf/FIDS_Zarządzanie_ryzykiem_nadużyć.pdf, s. 12, 37.

${ }^{2}$ Global Corruption Barometer 2009, Transparency International, http://www.transparency. org/policy_research/surveys_indices/gcb/2009. 
teraz na sektor prywatny wskazało 59\% respondentów (w Singapurze - 66\%). W USA za najbardziej skorumpowaną instytucję uznano legislaturę - 30\% badanych, ale sektor prywatny znalazł się już na drugiej pozycji przy $22 \%$ wskazań (w Kanadzie była to pierwsza pozycja - 32\%) ${ }^{3}$.

Według badań CBOS z kwietnia 2009 roku dziedziny życia, w których zdaniem Polaków korupcja występuje najczęściej, to polityka i służba zdrowia (odpowiednio - 55\% i 54\% wskazań). Firmy prywatne znalazły się na ósmej pozycji - 10\% respondentów i ta liczba znacząco się nie zmieniała w siedmiu badaniach od 2001 roku, gdy było to $13 \%{ }^{4}$. Firma Deloitte w tytule swego raportu nazwała nadużycia „niewidzialnym wrogiem przedsiębiorstw”. W badaniach z 2008 roku polskie firmy uznały za najbardziej powszechne łapownictwo i korupcję $(80,4 \%)$, przed m.in.: fałszowaniem sprawozdań finansowych, przestępczością zorganizowaną, wykorzystaniem konfliktu interesów, przestępstwami popełnianymi za pomocą komputera oraz kradzieżą informacji i własności intelektualnej. Także za najbardziej dotkliwe badani uznali łapownictwo i korupcję $(42,2 \%)^{5}$. W badaniach Ernst \& Young z 2008 roku wśród przedstawicieli dużych przedsiębiorstw z 33 krajów co czwarta osoba nim objęta stwierdziła, że w ostatnich 2 latach w jej firmie wystąpił przypadek korupcji lub łapownictwa. 23\% respondentów było w stanie podać przykład, w którym od pracownika ich firmy starano się pozyskać łapówkę w zamian za pozyskanie lub kontynuację biznesu. 18\% badanych przyznawało, że wie o sytuacji, w której ich firma straciła zamówienie lub kontrakt na rzecz konkurenta, który wręczył łapówkę.

Korupcja może być rozważana zarówno w obrębie konwencjonalnej, jak i nieortodoksyjnej ekonomii. Jako że korupcja w sektorze prywatnym jest sposobem maksymalizowania użyteczności i dokonywania wyborów, można ją opisywać w obrębie analizy mikroekonomicznej, posługując się tradycyjnymi narzędziami, w tym indywidualizmem metodologicznym. Problem polega na tym, że przedmiotem wymiany nie jest dobro publiczne, ale prywatne. Gdy przekazywane jest przez dysponenta poniżej ceny rynkowej, oznacza to, że przyczyny mogą mieć charakter własnościowy (oddzielenie własności i zarządzania) oraz organizacyjny (powierzenie zasobów firmy osobie dysponującej, za nie odpowiedzialnej). Kosztem i jednocześnie zyskiem osoby otrzymującej nieuprawnione w sensie legalności korzyści jest z jednej strony łapówka, z drugiej zaś strata przedsiębiorstwa.

\footnotetext{
${ }^{3}$ Ibidem.

${ }^{4}$ Opinia spoteczna o korupcji w Polsce. Komunikat z badań, CBOS, Warszawa 2009, s. 24, 25.

${ }^{5}$ Nadu̇̇ycia - niewidzialny wróg przedsiębiorstw 2008. Raport z badania nadużý gospodarczych w polskich firmach, Deloitte, http://www.deloitte.com/dtt/cda/doc/content/pl_NaduzyciaGospodarcze_2008. pdf, s. 10 .

${ }^{6}$ Korupcja czy zapewnienie zgodności - co więcej kosztuje? X światowe badanie nadużý́ gospodarczych, Ernst \& Young, http://webapp01.ey.com.pl/EYP/WEB/eycom_download.wsf/resource/Report_korupcja_2008.PDF.
} 
Jednostki przyjmują stopień swojej racjonalności w zależności od posiadanych zasobów i funkcjonujących instytucji. W analizie instytucjonalnej korupcji można wykorzystać odpowiednie wątki ekonomicznej teorii zachowań ludzkich, teorii gier, wyboru publicznego, teorii praw własności, interesów grupowych, kosztów transakcyjnych, kosztów behawioralnych, teorii klubów, pryncypała-agenta, asymetrii informacyjnej, capture theories, pogoni za rentą, modeli kolejek (queving models), teorii organizacji (patologii i dysfunkcji organizacji). Instytucje nieformalne to postawy moralne, zwyczaje i rutyna, w dużym stopniu samoorganizujące się reguły. Ich stabilność jest największa, co powoduje, że próby zmian norm formalnych, które są sprzeczne z normami społecznymi, natrafiają na trudności ${ }^{7}$. W tych ujęciach korupcja może być instytucją, trwałą formą wzajemnych stosunków między ludźmi, redukującą niepewność poprzez wprowadzenie struktury do ludzkich interakcji. Wymiana korupcyjna zawiera w sobie elementy przyjmowane przez teorię kosztów transakcyjnych, czyli niepewność, rolę częstotliwości transakcji, specyficzność zasobów, oportunizm i ograniczoną racjonalność. Występują koszty zbierania informacji o podmiocie korumpowanym, przetargów i gier z nim prowadzonych, ewentualnego egzekwowania usługi, ryzyka. Cena wymiany może mieć charakter zindywidualizowany lub określony na danym rynku w wyniku powszechności i ciągłości. Nowa ekonomia instytucjonalna przyjmuje założenie o niepewności losowej i niepewności behawioralnej wynikającej z oportunizmu ludzi, który według Olivera Wiliamsona polega na podstępnym poszukiwaniu renty za pomocą zniekształcania informacji, oszustwa itp. Towarzyszy temu asymetria informacji posiadanych przez strony kontraktu ${ }^{8}$. Kontrakty kompletne, które występują na rynku doskonałym, oparte na doskonałej informacji, zastąpione zostały przez pojęcia kontraktów niekompletnych, nieformalnych i niewiążących strony ${ }^{9}$.

Zagrożenia korupcyjne wynikają z obowiązujących praw własności. Wymiana dóbr jest transferem praw własności. „Moc, z jaką posiadane są prawa, może być określona przez stopień, w jakim decyzja posiadacza danego prawa dotycząca sposobu użytkowania danego dobra rzeczywiście wyznacza sposób, w jaki to dobro jest użytkowane"10. Efektywne prawa własności muszą być wyłączne oraz odstępowalne (transferowalne), co pozwala istnieć rynkom efektywnym. Struk-

${ }^{7} \mathrm{~J}$. Małysz, Instytucje a koszty transakcyjne w świetle neoinstytucjonalnej ekonomii, „Ekonomista” 2003, nr 3, s. 321.

${ }^{8}$ O. Williamson, Ekonomiczne instytucje kapitalizmu, PWN, Warszawa 1998, s. 60; B. Klimczak, Dziatania grup interesu w okresie transformacji - teoria i zastosowanie, „Ekonomista” 2002, nr 4, s. 508.

${ }^{9}$ E. G. Furubotn, R. Richter, Institutions and Economic Theory, University of Michigan Press, Ann Arbor 1997.

${ }^{10}$ A. Alchian, H. Demsetz, The Property Rights Paradigm, „The Journal of Economic History" 1973 , vol. 33, s. 17. 
tura praw właścicielskich wywiera wpływ na koszty transakcyjne i zachowania ekonomiczne podmiotu gospodarczego na rynku, także na jego skłonność do uczestnictwa w relacji korupcyjnej. Przedstawiciele tego wątku nowej ekonomii instytucjonalnej akcentują fakt, że zmiana charakteru własności nie tylko zmienia stosunki społeczne w procesie produkcji i dystrybucji, ale także zmienia stosunek podmiotów do zasobów. Wynika to z tego, że wartość danego zasobu z punktu widzenia podmiotu jest uzależniona od jego praw do tego zasobu.

Ewolucja praw własności i asymetria informacji prowadzą do kolejnego zagadnienia ujętego w teorii agencji, dotyczącego także sektora prywatnego, a szczególnie spółek. Aby wystąpił problem agencji, muszą być spełnione następujące warunki ${ }^{11}$ : rozbieżność interesów pryncypała i agenta, występowanie niepewności, niepełna możliwość obserwacji zachowań agenta, występowanie kosztów zawarcia i wykonania kontraktu między pryncypałem a agentem, niekompletność kontraktów i asymetria informacyjna. Rola agenta i jego autonomia stwarzają zagrożenie uczestnictwa w korupcji, także w relacjach $\mathrm{z}$ innymi agentami.

Zachowania korupcyjne w obrębie firm i między nimi ująć można w ramach ekonomicznej teorii behawioralnej. Podejmuje ona problem działań menedżerów i pracowników w warunkach niepewności, które to działania mogą im przynosić korzyści kosztem przedsiębiorstwa. „Im bardziej istotna dla organizacji będzie sfera niepewności kontrolowana przez danego aktora, tym większą będzie on dysponował władzą"12. Wbrew koncepcji neoklasycznej cele firmy to wiązka celów będąca wynikiem przetargu i osiągania konsensusu. W nawiązaniu do koncepcji nieefektywności X pojawia się tu zagadnienie „luzu organizacyjnego”, który istnieje dzięki temu, że efektywność faktyczna jest mniejsza niż maksymalna i utrzymuje się na poziomie satysfakcjonującym, czyli niezbędnym do przetrwania. „Ludzie zachowują się tak, jak im się podoba, albo tak, jak uważają, że muszą postępować, albo też wybierają jakieś kompromisowe rozwiązanie między tymi dwiema możliwościami”13. Oprócz typowej racjonalności wpływ na ludzi ma m.in. naśladownictwo, oceny odruchowe, zmienność oceny kosztów i efektów, a nawet przyjemność dokonywania wyboru irracjonalnego. To jest to, co kiedyś z pewnym przybliżeniem Janos Kornai nazwał regulacją autonomiczną (wegetatywną) ${ }^{14}$. Unika się kosztu wyszukiwania nowych pozycji, zerwania istniejących relacji społecznych, które rodzą nowe niepewności. Zasadniczym pojęciem w tym kontekście jest in-

${ }^{11}$ M. Gorynia, Przedsiębiorstwo w nowej ekonomii instytucjonalnej, „Ekonomista” 2001, nr 6, s. 779-780.

${ }^{12}$ M. Crozier, E. Friedberg, Cztowiek i system. Ograniczenia dziatania zespotowego, PWE, Warszawa 1982, s. 78.

${ }^{13}$ H. Leibenstein, Poza schematem homo oeconomicus, PWN, Warszawa 1988, s. 126.

${ }^{14} \mathrm{~J}$. Kornai, Anri-Equilibrium. Teoria systemów gospodarczych, PWN, Warszawa 1977, s. 238. 
ercja. Oznacza to, że możliwe są „,stabilne rozwiązania nieoptymalne” ${ }^{15}$.Zazwyczaj teoria ekonomii za główne źródło nieefektywności uznawała niewłaściwą alokację zasobów. Harvey Leibenstein twierdził, że kalkulacja ludzka ma charakter przybliżony, a zachowanie jednostek w organizacji oparte jest też na inercji i tym, co nazwał nieefektywnością X, która jest nawet większa od nieefektywności alokacyjnej zasobów. Rozmiary korzyści osiąganych dzięki zwiększeniu efektywności alokacyjnej są znikome, natomiast korzyści osiągane dzięki zwiększeniu efektywności X często są znaczne. Składa się na nią indywidualna efektywność związana z motywacją, motywacyjna efektywność wewnątrzzakładowa, zewnętrzna efektywność motywacyjna oraz efektywność nakładów nierynkowych. Przyczynami nieefektywności X są: niekompletność umów o pracę, niewyspecyfikowana lub nie w pełni znana funkcja produkcji, nie wszystkie nakłady oferowane są na rynku lub jeżeli nawet są, to nie są dostępne dla wszystkich nabywców na jednakowych warunkach, i wreszcie efektywność wykorzystania danego nakładu zależy od stopnia presji motywacyjnej, a także od innych czynników motywacyjnych ${ }^{16}$. Do ważnych umiejętności kierownika należy także zdolność pozyskiwania czynników produkcji, które nie są przedmiotem normalnej wymiany. „W krajach słabo rozwiniętych zdolność uzyskania środków finansowych może zależeć od powiązań rodzinnych [...]. Pewnego typu informacja rynkowa może być dostępna dla niektórych osób, a jednocześnie nie da się jej kupić na rynku"17. Taka informacja może także wynikać z uczestnictwa w sieciach korupcyjno-klientelistycznych.

W szerokich definicjach korupcji mieszczą się relacje w obrębie sektora prywatnego. W literaturze spotykamy definicje korupcji jako czynu, który popełnia każdy, kto powodowany swoimi bezpośrednimi lub pośrednimi interesami narusza system reguł, za realizację których sam jest odpowiedzialny ${ }^{18}$. Według Kennetha Jowitta korupcja odnosi się do sytuacji, w której członkowie organizacji mylą lub zrównują własne jednostkowe interesy z podstawowymi interesami organizacji, a szefowie organizacji ponoszą porażkę w sprawnym ustanowieniu różnicy między ogólnymi a partykularnymi interesami ${ }^{19}$. W raporcie ACFE - Stowarzyszenia Ekspertów ds. Wykrywania Oszustw i Nieprawidłowości, korupcja to forma oszustw i nadużyć, niewłaściwe wykorzystywanie swoich wpływów na transakcje handlowe, w celu osiągnięcia korzyści majątkowej dla siebie lub osób trzecich, wbrew swoim obowiązkom wobec pracodawcy ${ }^{20}$.

${ }^{15}$ H. Leibenstein, op. cit., s. 258.

${ }^{16}$ Ibidem, s. 24, 81-82, 85, 195.

${ }^{17}$ Ibidem, s. 83.

${ }^{18}$ A. A. Rogow, H. D. Laswell, Power, Corruption and Rectitude, Prentice Hall, New York, Englewood Cliffs 1963.

${ }^{19}$ K. Jowitt, Soviet neotraditionalism: the political corruption of leninist regime, „Soviet Studies”, July 1983, vol. 35, no. 3, s. 293.

${ }^{20} \mathrm{http}: / /$ www.acfe.pl./pl./iofficilfilel/raport_to_the_nation_PL.pdf. 
Pochodnym lub sprzyjającym korupcji zjawiskiem występującym szczególnie w rozwiniętych krajach zachodnich jest crony capitalism (kronizm). Pierwszy raz słowa crony, w znaczeniu: pierwotna, długookresowa przyjaźń lub związek ludzi, użył Samuel Pepys w 1665 roku w kontekście osób, które były związane z uniwersytetami w Cambridge i Oxford (znajomi ze szkoły). Od XX wieku crony ma negatywne konotacje ${ }^{21}$. Przypomina występujące na szeroką skalę zjawiska faworytyzmu, a w jego obrębie nepotyzmu i kumoterstwa, które z pewnym kolokwializmem można by było nazwać kapitalizmem kolesiów. Kronizm jest także definiowany jako sieci powiązań poziomych wśród znajomych (cronies), którzy ulokowani na swoich pozycjach podtrzymują lub promują się wzajemnie, w zależności od tego, kto aktualnie ma władzę ${ }^{22}$. Crony capitalism, rozdzielenie własności i zarządzania powodują, że nie zawsze interesy właścicieli są na pierwszym planie. Oznacza to, że pogoń za rentą może występować także w obrębie prywatnych firm (internal rent seeking) jako, przykładowo, konkurencja między grupami pracowniczymi o udział w zyskach czy po prostu o miejsca pracy.

Korupcję w sektorze prywatnym możemy pogrupować według poziomów występowania na:

- małą, dotyczącą mniejszych korzyści, która może jednak być rozpowszechniona głównie wśród pracowników niższego szczebla;

- wielką, dotyczącą większych korzyści pieniężnych i niepieniężnych, głównie wśród kadry kierowniczej, menedżerskiej, zarządów czy rad nadzorczych, czyli związaną z elitami gospodarczymi.

Elemer Hankiss stosuje podział korupcji według stopnia przyzwolenia na ${ }^{23}$ :

- „białą” o dużej tolerancji społecznej;

- „szarą" o niejednolitej ocenie społecznej;

- „czarną” o negatywnej ocenie.

Według zakresu korupcję dzielimy na ${ }^{24}$ :

- zindywidualizowaną (ograniczona liczba osób). To także prosta korupcja (simple corruption) - podstawa piramidy, odnosi się głównie do łapówek i angażuje w transakcje 2 osoby;

- zbiorową - angażującą całe grupy interesów po dwóch stronach relacji.

Korupcja w organizacji może mieć także charakter zbiorowy, gdy premie finansowe dla pracowników odrywają się od wyników finansowych organizacji.

${ }^{21}$ J. S. Kahn, F. Formosa, The Problem of Crony capitalism: Modernity and Encounter with the Perverse, „Thesis Eleven” 2002, no. 69, s. 50-51.

${ }^{22} \mathrm{~J}$. Waterbury, An Attempt to Put Patrons and Clients in Their Place, [w:] E. Gellner, J. Waterbury (eds.), Patrons and Clients in Mediterranean Societies, Duckworth, London 1977.

${ }^{23}$ E. Hankiss, Putapki spoteczne, Wiedza Powszechna, Warszawa 1986.

${ }^{24}$ E. Savona, L. Mezzanotte, La corruzione in Europa, Roma 1998, za: P. Langseth, Vallue Added of Partnership in the Fight against Corruption, UN ODCCP, Vienna, March 2001, s. 2. 
W okresie prosperity w 2005 roku bankierzy z londyńskiej City i nowojorskiego Wall Street rozdzielili między sobą 35 mld USD samych tylko premii. W ciągu zaledwie dwóch dekad suma premii wypłacanych w bankach z Wall Street wzrosła z 1,9 mld USD (1985 r.) do 34,1 mld USD w szczytowym roku 2006 (wzrost o 1695\%). W 2007 roku Wall Street i City wypłacily w sumie 45 mld USD premii. Londyńskie City wypłaciło za 2008 rok 3,6 mld funtów premii, a na Wall Street w roku 2008 - 18,1 mld USD ${ }^{25}$. Dochodzi do tego problem różnic w wynagrodzeniach. W latach 30. w USA osoby w zarządach korporacji zarabiały 120 razy więcej niż „średni pracownicy”. Obecnie jest to $320 \mathrm{razy}^{26}$. To także może być forma nadużycia, które mieści się w szerokiej definicji korupcji.

\section{PRAWNE ASPEKTY KORUPCJI W SEKTORZE PRYWATNYM}

Prawna walka $z$ korumpowaniem urzędników publicznych przez firmy prywatne ma swą prekursorską amerykańską Ustawę o zagranicznych praktykach korupcyjnych (Foreign Corrupt Practices Act - FCPA) jeszcze z 1977 roku, która jednak wobec braku bliźniaczych ustaw $w$ innych krajach stawiała firmy z USA w trudniejszej sytuacji przy zawieraniu kontraktów za granicą. W 1933 r. Kongres USA wprowadził nakaz oddzielenia dwóch typów działalności banku - detalicznej i inwestycyjnej (tzw. ustawa Glassa-Steagalla). Ponadto wyodrębniono bankowość od działalności ubezpieczeniowej. Uzasadnieniem były odmienne sposoby oceny ryzyka oraz możliwość konfliktu interesów. Konflikt mógł polegać np. na tym, że osoby z działu komercyjnego udzielały kredytów danej firmie, ponieważ ich koledzy z firmy inwestycyjnej doradzali przy emisji i byli wynagradzani procentem od uplasowanych papierów. Błędem okazało się uchylenie ustawy Glassa-Steagalla w czasie prezydentury Clintona w 1999 roku. Jeszcze w latach 80. banki inwestycyjne zmieniły formę prawną ze spółek partnerskich w spółki akcyjne, co zmieniło nie tylko formę odpowiedzialności, ale też wprowadziło zmianę kulturową. Stąd sygnalizowana obecnie potrzeba powrotu do ustawy Glassa-Steagalla. Współczesne skandale biznesowe, jak w firmie Enron, doprowadziły do nowych rozwiązań prawnych. Przykładem jest ustawa SOX (Sorbanes-Oxley) w USA, która ustaliła zasady wewnętrznego monitoringu $\mathrm{w}$ firmach przeciwdziałające nadużyciom zarządów i rad, wprowadzająca nowe narzędzia zewnętrznej kontroli, w tym także przez niezależnych od firmy audytorów. Szefowie firm mają ponosić osobistą odpowiedzialność za zgodność raportów finansowych z rzeczywistością, nie będą mieli prawa pozyskiwać od przedsiębiorstw osobistych pożyczek, ich

\footnotetext{
${ }^{25}$ Attacking the corporate gravy train, „The Economist” z 30.05.2009, s. 71-73.

${ }^{26}$ In the money. A special report on executive pay, „The Economist” z 20.01.2007, s. 4.
} 
dochody będą publicznie znane, a audytorzy niezależni. Podniesiono także kary za nierzetelną sprawozdawczość. W ten sposób prawo próbuje regulować nowe zjawiska, które kiedyś eliminowały postawy oparte na religii, kulturze i zwyczaju. Wszystko to są jednak instytucje prawne funkcjonujące w obrębie USA.

W skali międzynarodowej pierwszym ważnym uregulowaniem dotyczącym korupcji w sektorze prywatnym była zatwierdzona w dniu 21 listopada 1997 roku Konwencja OECD o zwalczaniu przekupstwa zagranicznych funkcjonariuszy publicznych w międzynarodowych transakcjach handlowych. W dniu 22 grudnia 1998 roku Rada Unii Europejskiej przyjęła na podstawie art. K.3 Traktatu o Unii Europejskiej Wspólne Działanie w sprawie korupcji w sektorze prywatnym (98/742/WSiSW), gdzie korupcja bierna to umyślne zachowanie osoby, która, w toku wykonywania swych czynności zawodowych, bezpośrednio bądź przez pośrednika żąda lub otrzymuje nielegalną korzyść jakiegokolwiek rodzaju albo akceptuje obietnicę udzielenia takiej korzyści sobie bądź osobie trzeciej, w zamian za dokonanie lub zaniechanie dokonania jakiejś czynności wbrew jej obowiązkom. Znów korupcja czynna w sektorze prywatnym to rozmyślne składanie obietnic, oferowanie bądź wręczanie przez kogokolwiek, bezpośrednio albo przez pośrednika, nielegalnej korzyści jakiegokolwiek rodzaju osobie, dla niej samej lub dla osoby trzeciej, w toku wykonywania przez nią czynności zawodowych, dla skłonienia jej do dokonania albo zaniechania dokonania jakiejś czynności wbrew obowiązkom. Określono też odpowiedzialność osób prawnych.

W 2002 roku Polska ratyfikowała dwie fundamentalne konwencje mające znaczenie w poprawie efektywności zwalczania korupcji w sektorze prywatnym:

- prawnokarną konwencję o korupcji, sporządzoną w Strasburgu 27 stycznia 1999 roku,

- cywilnoprawną konwencję o korupcji, sporządzoną w Strasburgu 4 listopada 1999 roku.

„Konwencja o przeciwdziałaniu korupcji w prawie cywilnym” Rady Europy zgodnie $\mathrm{z}$ art. 2 stwierdza, że korupcja to żądanie, oferowanie, wręczanie lub przyjmowanie bezpośrednio lub pośrednio łapówki lub każdej innej nienależnej korzyści, które powodują wypaczanie właściwego wykonywania obowiązków lub zachowania wymaganego od osoby, która przyjęła łapówkę, nienależną korzyść lub zaakceptowała jej obietnicę ${ }^{27}$. Do tej definicji nawiązuje określenie przestępstwa korupcji w sektorze prywatnym wyrażone przez Konwencję Prawnokarną Rady Europy z 27 stycznia 1999 roku. Podobnie definiuje się tam korupcję czynną i bierną jak w sytuacji dotyczącej funkcjonariusza publicznego. Konwencja prawnokarna nałożyła na państwa będące sygnatariuszami konwencji zobowiązanie do

${ }_{27}$ Konwencja o przeciwdziataniu korupcji w prawie cywilnym, Rada Europy, Strasburg 4.11.1999, Ośrodek Informacji Rady Europy, Centrum Europejskie UW, 1999, Biuletyn 3-4, s. $168-173$. 
podejmowania szeregu środków na szczeblu krajowym. Dotyczy osób kierujących lub pracujących w jakimkolwiek charakterze na rzecz jakiegokolwiek podmiotu należącego do sektora prywatnego. Obejmuje kierownictwo firmy, szeregowych pracowników, jak i osoby, które $\mathrm{z}$ danym podmiotem łączą stosunki cywilnoprawne. Uznano, że w sektorze prywatnym najważniejsza jest więź lojalności łącząca pracownika i pracodawcę. Naruszenie obowiązków to także naruszenie interesu pracodawcy, wynikającego ze specyfiki funkcjonowania w sektorze prywatnym. Postanowiono, że odpowiedzialności karnej winny podlegać nie tylko osoby fizyczne, lecz również osoby prawne, w przypadku gdy działanie osoby fizycznej mającej wiodącą rolę w ramach osoby prawnej było dokonane na jej korzyść. Konwencji tej towarzyszyło Porozumienie ustanawiające Grupę Państw przeciwko Korupcji (GRECO).

W dniu 22 lipca 2003 roku Rada Unii Europejskiej uznała, że wzrost transgranicznego handlu towarami i usługami uzasadnia zajęcie się zagadnieniem korupcji w sektorze prywatnym, i przyjęła Decyzję ramową nr 2003/568/WSiSW Rady w sprawie zwalczania korupcji w sektorze prywatnym. Państwa członkowskie zostały zobowiązane do podjęcia takich działań ustawodawczych, by czyny korupcji w sektorze prywatnym podlegały skutecznej, proporcjonalnej i odstraszającej karze. Decyzja ramowa 2003/568/WSiSW definiuje pojęcia korupcji czynnej i biernej w sektorze prywatnym, odnosząc je do „działań gospodarczych”, czyli pomiędzy podmiotami gospodarczymi, w ramach podejmowanej działalności gospodarczej. Osoby prawne oprócz kary grzywny winny podlegać sankcjom takim, jak: wyłączenie prawa do korzystania ze świadczeń publicznych lub pomocy publicznej, czasowy lub stały zakaz prowadzenia działalności gospodarczej, przekazanie pod nadzór sądowy, sądowy nakaz likwidacji.

Innym międzynarodowym aktem prawnym normującym działania w obrębie sektora prywatnego jest Konwencja Narodów Zjednoczonych przeciwko korupcji, przyjęta w dniu 31 października 2003 roku przez Zgromadzenie Ogólne NZ w rezolucji nr 58/4. Konwencja zawiera definicję korupcji dotyczącej zarówno sektora publicznego, jak i prywatnego, zasady kryminalizacji oraz współpracy międzynarodowej w zakresie zwalczania tego zjawiska. W Konwencji nakazuje się ścigać czyny korupcyjne dokonywane przez lub wobec każdej osoby, która w jakimkolwiek charakterze kieruje bądź pracuje na rzecz jednostki gospodarczej działającej w sektorze prywatnym. Konwencja zawiera także inne regulacje materialnokarne. Nakazuje się w niej wprowadzenie odpowiedzialności osób prawnych za czyny korupcyjne, przy czym może ona mieć charakter karny, cywilny lub administracyjny, w zależności od zasad prawnych obowiązujących w danym państwie. Polska podpisała Konwencję Narodów Zjednoczonych przeciwko korupcji w dniu 10 grudnia 2003 roku i dostosowała się do innych wymogów prawa międzynarodowego. Pozyskiwanie kontrahentów czy ograniczanie konkurencji 
za pomocą różnego rodzaju niedopuszczalnych korzyści majątkowych czy osobistych, czyli „korupcja w sektorze prywatnym”, została spenalizowana na gruncie polskiego prawa karnego ${ }^{28}$. Kodeks karny zakłada, że korupcja w życiu gospodarczym jest poważną przeszkodą w rozwoju ekonomicznym kraju. Prowadzi do ubożenia oferty handlowej, nieuzasadnionego ekonomicznie wzrostu cen, godzi w podstawową zasadę gospodarki, jaką jest wolna konkurencja. Podział zjawiska korupcji na czynną i bierną został odzwierciedlony w poszczególnych modelach i typach korupcji przyjętych w polskim kodeksie karnym Ustawą z dnia 13 czerwca 2003 roku o zmianie ustawy Kodeks karny oraz niektórych innych ustaw (Dz. U., nr 111, poz. 1061), która weszła w życie 1 lipca 2003 roku $^{29}$. Do grupy przestępstw korupcyjnych, które obejmuje obszar sektora prywatnego w kodeksie karnym, należą m.in.: korupcja gospodarcza (korupcja menedżerów) art. 296a k.k., korupcja w zawodach sportowych art. 296b k.k., korupcja wierzycieli art. 302 § 2 i 3 k.k.

Korupcja menedżerów dotyczy tego, kto pełniąc funkcję kierowniczą w jednostce organizacyjnej wykonującej działalność gospodarczą lub pozostając z nią w stosunku pracy, umowy-zlecenia lub umowy o dzieło, żąda lub przyjmuje korzyść majątkową lub osobistą albo jej obietnicę, w zamian za nadużycie udzielonych mu uprawnień lub niedopełnienie ciążącego na nim obowiązku mogącego wyrządzić tej jednostce szkodę majątkową lub stanowiącą czyn nieuczciwej konkurencji oraz niedopuszczalną czynność preferencyjną na rzecz nabywcy lub odbiorcy towaru, usługi lub świadczenia. Od 18 grudnia 2008 roku grupa osób odpowiedzialnych za przestępstwa przyjmowania korzyści majątkowej lub osobistej rozszerzyła się. Do tego czasu dotyczyło to tylko osób pełniących funkcje kierownicze w jednostce organizacyjnej (samodzielność decyzyjna). Według Ustawy z 24 października 2008 roku o zmianie ustawy Kodeks karny wprowadzono nowe brzmienie art. 296a k.k., a ustawodawca rozszerzył możliwość karania za przyjęcie korzyści majątkowej i osobistej lub ich obietnicy na każdego, kto pozostaje w stosunku pracy lub stosunku cywilnoprawnym. Art. 296a k.k. odwołuje się również do podmiotów, które faktycznie sprawują znaczącą funkcję w podejmowaniu działań gospodarczych w tejże jednostce. Są to często osoby związane z dokonywaniem zamówien, organizacją procesu produkcji czy zbytu. Można generalnie stwierdzić, iż jest to personel zarządzający niższego stopnia. „Bycie w strukturze organizacyjnej” nie oznacza jednak, że sprawcami mogą być wyłącznie pracownicy - zakres odnosi się także do wszelkiego rodzaju osób działających w przed-

${ }^{28} \mathrm{~W}$. Wróbel, Zmiana normatywna i zasady intertemporalne w polskim prawie karnym, Kantor Wydawniczy Zakamycze, Kraków 2003.

${ }^{29}$ R. Zawłocki, Podstawy odpowiedzialności karnej za przestępstwa gospodarcze, Wydawnictwo C. H. Beck, Warszawa 2004, s. 95; Nowela antykorupcyjna z dnia 13 czerwca 2003 r., wprowadzenie B. Mik, Kantor Wydawniczy Zakamycze, Kraków 2003. 
siębiorstwie na podstawie umów cywilnoprawnych. Penalizowaną w art. 296a §1 k.k. czynnością wykonawczą jest przyjęcie korzyści majątkowej lub osobistej albo jej obietnicy (także bardzo nieskonkretyzowanej, wyrażonej w formie aluzyjnej) ${ }^{30}$. Kodeks karny daje możliwość złamania solidarności pomiędzy uczestnikami korupcji w sektorze prywatnym w zamian za zawiadomienie organu powołanego o fakcie przestępstwa dokonanego przez łapownika czynnego.

Kluby sportowe w dużej części występują jako jednostki prywatne. Art. 296b k.k. (korupcja sportowa) stwierdza, że w relacji korupcyjnej jest ten, kto, organizując profesjonalne zawody sportowe lub w nich uczestnicząc, przyjmuje korzyść majątkową lub osobistą albo jej obietnicę w zamian za nieuczciwe zachowanie, mogące mieć wpływ na wynik tych zawodów.

Sektora prywatnego dotyczy też korupcja wierzycieli zarówno w wersji korupcji czynnej, jak i biernej. Przykładowo korupcja czynna jest wtedy, gdy wierzycielowi udziela się lub obiecuje udzielić korzyści majątkowej za działanie na szkodę innych wierzycieli w związku z postępowaniem upadłościowym lub zmierzającym do zapobiegnięcia upadłości. Przepis ten ma na celu ochronę prawidłowego, niezakłóconego nieuczciwymi i nierzetelnymi działaniami funkcjonowania obrotu gospodarczego w trakcie trwającego postępowania upadłościowego lub postępowania zmierzającego do zapobiegnięcia upadłości.

Sektor prywatny obejmują także przepisy Ustawy z dnia 28 października 2002 r. o odpowiedzialności podmiotów zbiorowych za czyny zabronione pod groźbą kary (Dz. U. z 2002 r., nr 197, poz. 1661 z późn. zm.). Odpowiedzialność ponosi również podmiot zbiorowy za czyn, którym jest zachowanie osoby fizycznej działającej w imieniu lub w interesie tego podmiotu gospodarczego, jeżeli zachowanie to przyniosło lub mogło przynieść podmiotowi zbiorowemu korzyść, chociażby niemajątkową.

Powyższe rozwiązania prawne nie tylko w sposób precyzyjny definiują korupcję w sektorze prywatnym, ale też wskazują, że nie tylko na świecie, ale także w Polsce dostrzeżono wagę zagrożeń dla gospodarki i społeczeństwa, tkwiących w tym zjawisku.

\section{WYBRANE PRZYCZYNY KORUPCI W SEKTORZE PRYWATNYM}

Relacje sieciowe są komponentem zasobu rynkowego nazwanego kapitałem społecznym, dlatego kapitał społeczny nazywany jest także kapitałem sieciowym. Kapitał społeczny to „sieć kontaktów, znajomości, powiązań, przynależności do

\footnotetext{
${ }^{30}$ Kodeks karny, część szczególna, t. 2, A. Wąsek (red.), Wydawnictwo C. H. Beck, Warszawa 2005, s. 1135.
} 
organizacji i stowarzyszeń, która stwarza jednostce lepsze możliwości uzyskiwania innych społecznie cenionych dóbr - bogactwa, władzy, prestiżu" ${ }^{31}$. W skali powszechnej, także w rozwiniętych gospodarkach rynkowych, występują nieformalne powiązania i zależności, sieci społeczne (network) obejmujące przykładowo członkostwo prestiżowych organizacjach w biznesu, pokrewieństwo kierownictw i właścicieli dużych przedsiębiorstw (kinship relation, family trees), znajomości i kontakty środowiskowe, wywodzące się często z okresu nauki w szkole, na studiach, działalności w organizacjach studenckich, sportowych. Ułatwia to np. poruszanie się po rynku pracy poprzez łatwiejszy dostęp do informacji, przepływ informacji, możliwość wywierania wpływu na pracodawców, większe szanse kariery zawodowej. W Polsce 70\% poszukujących pracy wykorzystuje znajomości, rodzinne stosunki i szuka protekcji ${ }^{32}$. Również badania w innych bardziej rozwiniętych krajach, w tym USA, potwierdzają znaczenie powszechnych nieformalnych kontaktów opartych na zaufaniu (np. rodzinnej rekomendacji) ${ }^{33}$.

Funkcjonowanie prenowoczesnych form społecznych i organizacji biznesowych (np. opartych na znajomościach) występuje w różnych krajach z różnym nasileniem. Wykorzystanie nieformalnych powiązań może przyczyniać się do poprawy funkcjonowania organizacji, usprawniając kanały komunikacji. Jest tak, dopóki indywidualni aktorzy nie zaczynają wykorzystywać sieci wzajemnych powiązań do realizacji partykularnych interesów, sprzecznych z celami organizacji. W skali globalnej korupcji sprzyja hierarchiczność struktur organizacyjnych i kumulacja władzy na najwyższych szczeblach korporacji oraz autonomia agentów. Również dominująca $z$ racji rozmiarów, wewnętrznej złożoności, pozycja firmy w życiu społecznym może osłabiać wrażliwość na patologię i sprzyjać poczuciu bezkarności wśród menedżerów. Kulturowe uwarunkowania wskazują, że granica między formami wdzięczności a łapownictwem może być bardzo płynna. Dlatego też, dokonując oceny zjawiska, należy łącznie rozważać takie okoliczności, jak: rozmiar i charakter przyjmowanej korzyści, jej cel, osobę przyjmującą korzyść, zwyczaj obowiązujący w danej grupie społecznej oraz stopień społecznej szkodliwości.

Wskażemy kilka charakterystycznych cech polskiego systemu gospodarczego sprzyjających korupcji komercyjnej. Jedną z głównych jest brak zaufania społecznego, jako zasadniczego składnika kapitału społecznego ${ }^{34}$. Polacy ufają rodzinie

31 P. Sztompka, Socjologia. Analiza spoteczeństwa, Wydawnictwo Znak, Kraków 2002, s. 368 .

${ }^{32}$ H. Januszek, Kapitat spoteczny na rynku pracy, [w:] B. Pogonowska (red.), Elementy etyki gospodarki rynkowej, PWE, Warszawa 2004, s. 3.

${ }^{33}$ J. Gardawski, L. Gilejko, J. Siewierski, R. Towalski, Socjologia gospodarki, Difin, Warszawa 2008 , s. 89.

${ }^{34}$ K. Nowakowski, Wymiary zaufania i problem zaufania negatywnego w Polsce, „Ruch Prawniczy, Ekonomiczny i Socjologiczny” 2008, nr 1. 
i najbliższym, ale nie obcym i instytucjom, co potwierdzają liczne badania. Przy średniej w Unii Europejskiej dla 2004 roku - 32\%, odsetek osób ufających innym ludziom w Polsce wynosił w poszczególnych latach: 1992 - 10,3\%, 1993 - 9\%, $1994-8,4 \%, 1995-8,4 \%, 1997-10,3 \%, 1999-12,4 \%, 2002-13,8 \%, 2003$ - 10,5\%, 2005 - 10,5\%, 2007 - 11,5\% ${ }^{35}$. Spersonalizowane, partykularne zaufanie dominujące w Polsce tworzy kapitał społeczny, który służy raczej skutecznej realizacji interesów partykularnych niż dobru wspólnemu i powoduje to, co Edward C. Banfield nazwal „amoralnym familizmem” ${ }^{36}$. Według Piotra Sztompki korupcja nie jest przyczyną załamania zaufania, lecz przeciwnie - to brak zaufania wywołuje korupcję $e^{37}$. Pracownicy polscy nie mają zaufania do kolegów, przełożonych oraz firmy, w której pracują. Tylko 23\% pracowników zgłosiłoby swojemu bezpośredniemu przełożonemu podejrzenie o popełnienie nadużycia (średnio w Europie - 40\%). Aż 26\% pracowników jest zdania, że pracodawca nie chroniłby należycie ich praw w przypadku zgłoszenia podejrzenia o popełnieniu nadużycia lub korupcji (średnia dla Europy jest o połowę niższa ${ }^{38}$ ). Bezpośredni przełożony powinien być punktem pierwszego kontaktu pracownika w przekazywaniu informacji o nadużyciach. W Europie Środkowo-Wschodniej zrobiłoby to $63 \%$ badanych, a w Europie Zachodniej - 79\% ${ }^{39}$. To specyfika kulturowa nie tylko polska, ale też regionalna.

Kolejnym czynnikiem sprzyjającym korupcji jest kultura organizacyjna - najważniejszy element kultury ekonomicznej, która znów jest elementem kultury narodowej. „Wśród narodowych systemów kulturowych i właściwych im wartości i wzorów zachowań mieszczą się także wartości i wzory regulujące zachowania ludzi w trakcie pracy. To jest właśnie kultura organizacyjna danego narodu" ${ }^{40}$. Powstająca spontanicznie lub świadomie kultura organizacyjna firm bywa wsparciem dla praktyk korupcyjnych. Może przekształcać się w „kulturę korupcyjną”. Tworzy ją, obok niekompetentnego zarządzania, złych procedur kontrolnych, atmosfera zastraszania personelu, blokowania przepływu informacji, a także zwyczajna chciwość menedżerów ${ }^{41}$. „Wschodnioeuropejską kulturę organizacyj-

35 Social Capital. Special Eurobarometer, European Commision, February 2005, s. 41; J. Czapiński, Kapitat spoteczny, [w:] J. Czapiński, T. Panek, Diagnoza spoteczna 2007. Warunki i jakość życia Polaków, Rada Monitoringu Społecznego, Warszawa 2007, s. 271.

${ }^{36}$ E. Banfield, The Moral Basis of Backword Society, Glencoe, IL: Free Press, London 1958.

${ }^{37}$ P. Sztompka, Nie ufaj nikomu, „Gazeta Wyborcza” z 1-2.12.2007, nr 281, s. 20.

${ }^{38}$ Nadużycia z perspektywy szeregowego pracownika, Ernst \& Young 2007, http://webapp01.ey com.pl/EYP/WEB/eycom_download.nsf/resorces/FIDS_ZarządzanieRyzykiemNadużyć_Polska.pdf.

${ }^{39}$ Zarzqdzanie ryzykiem nadużyć, Ernst \& Young 2007, htttp://weba01.com.pl/EYP/WEB/ eycom_download.nsf/FIDS_Zarządzanie_ryzykiem_nadużyć.pdf, s. 24.

${ }^{40} \mathrm{~J}$. T. Hryniewicz, Polityczny i kulturowy kontekst rozwoju gospodarczego, Wydawnictwo Naukowe Scholar, Warszawa 2004, s. 195.

${ }^{41}$ A. Dylus, Kulturowe uwarunkowania korupcji. Doświadczenia Polski, [w:] A. Dylus, A. Ru- 
ną wyróżnia silniejszy niż na zachodzie Europy kolektywistyczny partykularyzm i personalizm, co oznacza, że bezosobowe reguły i indywidualne zobowiązania wobec takich abstrakcyjnych wartości jak uczciwość, dość często ustępują zobowiązaniom osobistym wobec członków własnych grup rodzinno-koleżeńskich"42. Przejawia się ukształtowana już w XVI wieku folwarczna kultura organizacyjna, którą obecnie można określić jako neofolwarczną. Była to typowa organizacja całościowa nastawiona na regulacje zachowań personelu w pracy i życiu osobistym. Istotą wzajemnych stosunków był paternalizm. Ten typ organizacji oparty jest na nieformalnych transakcjach ekonomicznych, w tym korupcyjnych, i nie sprzyja tworzeniu nowoczesnych stosunków rynkowych ${ }^{43}$. Oprócz tego neofolwarczne stosunki pracy tłumią kreatywność i innowacyjność.

Brak zaufania społecznego i instytucjonalnego oraz specyficzna kultura organizacyjna ułatwiające korupcję wynikają $\mathrm{z}$ braku poczucia pewności i profesjonalizmu działania, nieumiejętności wyjścia poza schemat dotychczasowych doświadczeń, z braku odpowiednich wzorców zachowań przedsiębiorczych i zdrowych zasad konkurencji. Dla wielu firm korupcja stała się swoistym działaniem marketingowym, traktowanym jako normalny sposób na pozyskiwanie lub utrzymywanie klientów. Do tego dochodzi atmosfera społecznego przyzwolenia oraz chociażby to, że osoby ujawniające korupcję wewnątrz firmy nie są specjalnie chronione, a często wręcz piętnowane i zwalniane.

\section{ZAKOŃCZENIE}

Według przeprowadzonych na świecie badań, choć percepcję korupcji w firmach sygnalizowało $22 \%$ respondentów, to faktyczną praktykę korupcyjną stwierdziło 13\%. 89\% badanych w Polsce uważało, że ich firma nie była proszona o wręczenie łapówki (na świecie - 82\%, a w Europie Śródkowo-Wschodniej 70\%). W Polsce aż 80\% osób uznało, że ich firmy nie straciły żadnej możliwości biznesowej na skutek skorumpowania klienta przez konkurenta (na świecie - 76\% a w Europie Śródkowo-Wschodniej - 55\%). To dla Polski wyniki lepsze niż średnia światowa ${ }^{44}$. Potwierdzają to dane z 2006 roku, gdy Ernst \& Young przebadał 600 firm z 19 krajów (raport objął Polskę). W Europie Zachodniej

dowski, M. Zaborski (red.), Korupcja. Oblicza, uwarunkowania, przeciwdziatanie, Instytut Politologii Uniwersytetu Kardynała Stefana Wyszyńskiego w Warszawie, Zakład Narodowy im. Ossolińskich, Wrocław 2006, s. 115.

${ }^{42}$ J. T. Hryniewicz, op. cit., s. 261.

${ }^{43}$ Ibidem, s. 205-212.

${ }^{44}$ Economic crime: people, culture and controls, PricewaterhouseCoopers 2007, http://www.pwc. com/pl/eng/ins-sol/publ/2007/crime_survey_2007.pdf, s. 4. 
i USA z wymuszeniem łapówek czy oszustwami spotkało się 75\% badanych firm, w Polsce - tylko $32 \%{ }^{45}$. Oznacza to, że percepcja korupcji odbiega od faktycznego występowania tego zjawiska. Jest trudna do udowodnienia, tematem drażliwym, a firmy niechętnie przyznają się, iż padły jej ofiarą. Na wysoką percepcję korupcji wpływ mają media i politycy. Choć zasięg faktycznej korupcji może odbiegać od ogólnej pinii o zakresie jej występowania, nie ulega jednak wątpliwości, że jest to problem narastający, nie tylko w Polsce, ale i w skali światowej.

$\mathrm{Z}$ perspektywy firm główne jego skutki to: wzrost kosztów, straty finansowe, grzywny i kary, obniżenie morale pracowników, osłabienie reputacji firmy, wykluczenie z rynku, utrata kontrahentów, utrata zaufania udziałowców. Korupcja w sektorze prywatnym powoduje wypaczenie konkurencji, monopolizację, straty jakościowe (np. wady budowlane) i inne szkody wtórne. Walka z taką korupcją wymaga zwiększenia przejrzystości funkcjonowania firm, działań prewencyjnych, ale też zmiany postaw przyzwalających, ciągłego nacisku otoczenia społecznego przedsiębiorstwa oraz doskonalenia wymogów prawnych w skali krajowej i międzynarodowej.

Czas kryzysu w gospodarce jest czasem poszukiwania oszczędności i ograniczania nieefektywności X. Kryzys gospodarczy z jednej strony zwiększa determinację przedsiębiorców w nawiązywaniu kontraktów handlowych, $\mathrm{z}$ drugiej - daje możliwość do bardziej wnikliwych analiz, kontroli wydatków i dzięki temu ujawniania nadużyć, których w okresie koniunktury nie widać lub które są bagatelizowane.

\title{
CORRUPTION IN THE PRIVATE SECTOR
}

\author{
SUMMARY
}

Corruption is a universal and specific phenomenon of multifactor and multi aspect character and it embraces a lot of shades and types. This establishes a wide understanding of that phenomenon in social science and law. Corruption and bribery are types of fraud and are linked with the private sector too. Although certain types of corruption will decline as the private sector grows and consolidates, other new types involving private sector firms may increase. Commercial corruption can be described as relation inside of an organization and as relation between firms. Weak institutions, an uncertain rule of law, insecure property rights, a lack of corporate accountability encourage the kind of short term focus that causes corruption. Corruption in the private sector in Poland is connected with social distrust and specific organizational culture too. Such corruption is a genuine threat and creates new dangers for further development, causes loss of competitiveness and creates a substitute for fair market and competition in the Polish economy and abroad.

${ }^{45}$ L. Kostrzewski, Polska, Polska... Czy to tam, gdzie kradna??, „Rzeczpospolita” z 30.06.2006, nr 151 . 